\title{
Effect of replacing wheat-bran with cheka-residue as energy supplement on weight gain, nutrient digestibility and economic efficiency of Woyto-guji goats in Konso, Southern Ethiopia
}

\author{
Milkias Fanta Heliso*, Derrebe Kassa Hibebo and Getnet Kebede Kalsa \\ Southern Agricultural Research institute (SARI), P.O. Box. 2228, Arbaminch, Ethiopia. \\ *Corresponding author. Email: milkias.fanta@gmail.com; Tel: +251935493774.
}

Copyright (C) 2021 Heliso et al. This article remains permanently open access under the terms of the Creative Commons Attribution License 4.0, which permits unrestricted use, distribution, and reproduction in any medium, provided the original work is properly cited.

Received 29th December, 2020; Accepted 12th May, 2021

\begin{abstract}
The experiment was conducted on former Konso Woreda, now Konso Zone, Baide station. The aim of the study was to determine cheka-residue as an economic source of energy feed to replace wheat bran through evaluating its effect on weight gain and nutrient digestibility. Twenty intact yearling woyto-guji bucks selected from Baide CBBP association were divided in to five treatment groups each having four animal units. They were assigned to five experimental feeds [(Group-1/T1 = Grazing + 1.8 L cheka-residue; Group-2/T2= Grazing + $0.6 \mathrm{~L}$ cheka-residue + $132 \mathrm{~g}$ wheat bran; Group-3/T3= Grazing + 1.2 L cheka-residue + $68 \mathrm{~g}$ wheat bran; Group-4/T4= Grazing + $200 \mathrm{~g}$ wheat bran; Group-5/T5= Grazing only) in a completely block design. Equal amount of noug-seed-cake (100 g/anl/day) was given to all treatment groups. The study comprised 90 days of feeding +7 days digestibility trial. Supplementation after grazing tend to have increased $(p<0.05)$ live weight and nutrient digestibility of experimental goats in current study. The average daily gain of goats maintained with T1 and T4 were significantly higher $(p<0.05)$ than those of other treatments. Animals that received T1 and T4 had higher $(p<0.05)$ total dry matter $(D M)$, organic matter $(O M)$, crude protein $(C P)$ and crude fiber digestibility than in the remaining dietary treatments with T4 recording the highest value of $80.6 \%$ which was $12.81 \%$ higher than control. However, the two treatments (T1 and T4) were not different both in weight gain and nutrient digestibility reflecting that one can be used on place of the other. Besides, goats attained slaughter weight in a range of 29.9 to $31.8 \mathrm{~kg}$ as compared to $26.8 \mathrm{~kg}$ weight recorded for goats managed as control. Cheka-residue supplementation in current experiment provides more profit than others. Hence, it can be concluded that this by-product is a potential feed to replace wheat bran as it is very acceptable.
\end{abstract}

Keywords: Cheka-residue, digestibility, replace, wheat-bran, weight-gain, Woyto-guji goat.

\section{INTRODUCTION}

Goats play an essential role in improving the livelihoods of smallholder farmers in dry and harsh environments of tropical regions, providing meat, fibre, milk, skin, manure and short-term cash income (Aziz, 2010). Goats account for a large contribution of livestock to the countries' economy estimated at $47 \%$ of the agricultural GDP (Behnke, 2010). Their contribution to the total annual meat production is about $12 \%$ and together with sheep, they contribute about $90 \%$ of the live animal/meat and $92 \%$ of the total skin export trade value (FAO, 2004). Having high goat population size, Ethiopia stands third in Africa and sixth in the world accounting for $9 \%$ and $3 \%$ of the African and global goat population, respectively (FAOSTAT, 2016). About $70 \%$ of this population is found in the lowlands and the rest $30 \%$ is in highland (Ayalew et al., 2004).

Despite the huge goat population, coupled with insufficient efforts on the identification and structure of the 
goat populations, one possible contributing factor for minimal benefit could be the seasonal shortage of feed both in quantity and quality and the absence of a clear strategy to improve their production and productivity in Ethiopia (LMP, 2015). Goats are predominantly kept for meat production and managed in low-input, extensive grazing systems based on communal lands and native pastures in dry and harsh environments of tropical regions (Gebru et al., 2017). Pastoral and agro-pastoral are the predominant production systems in the arid and semi-arid agro-ecologies which are subsistence oriented and virtually depend on traditional management system with no or very limited external inputs (Gizaw et al., 2010).

Consequently, producers face many challenges that affect the productivity of their livestock enterprise. The main problems are low productivity and high mortality. This is primarily caused by inadequate nutrition, which results in low growth rates and small mature size, and is compounded by slaughtering of animals at immature body weights. Shortages of feed and health issues are often ranked as the most significant constraints to production (Gizaw et al., 2010). In many animal production systems, approximately two-thirds of improvements in livestock productivity can be attributed to improved nutrition. In economic terms, feed cost accounts for about $70 \%$ of the total cost of livestock production. The feasibility of livestock enterprises is, therefore, a function of the type of feed and feeding system. It is estimated that up to a five-fold increase in tropical livestock productivity can be attained if there is optimal feed resource utilization. Goat production in Ethiopia suffers from feed shortages at all levels with an estimated $40 \%$ deficit in the national feed balance. This is aggravated by seasonal availability of forage and crop residues in the highlands and by recurrent and prolonged drought in the lowlands (Gizaw et al., 2010). Improving performance through better nutrition is quite fundamental and this is dependent on three interrelated considerations: the availability of nutrients; type of feeding system; and the level of feeding management.

Cheka-residue is a by-product of the most commonly used traditional food and drink "Cheka" of peoples around Konso and Derashe with a slight difference in ingredients and methods of preparation. Konso peoples take the upper hand in using cheka, and they have a long history with it. Currently, cheka is found almost in all parts of southern Ethiopia due to its suitability to do hard works, availability of ingredients and low cost (Binitu et al., 2018). The common ingredients of cheka are sorghum, maize, malt and water which are all carbohydrates (energy source feeds) except water. Additional ingredients are used in different places, according to the availability of raw materials suitable for preparation. Derashe people for example use cabbage and Moringa leaf in addition to the common ingredients. The method and duration may differ due to the variation of ingredients. However, Konso's cheka takes the shortest time for preparation which is only about three days.

The primary goal of production of cheka in Konso area is to provide energy during hard works. Whenever the supernatant was used for human consumption, normally the bottom part of this product is untouched and left as a residue. Hence, huge volumes of these residues are getting accumulated in cheka producing areas that might have been developed as a strategy to lift productivity of goats based on higher quality forages and more efficient utilization of existing feed resources. However, there is no enough information available in the literature about the potential of cheka-residue to be used as an ideal source of energy feed for goats, and its effect on goat production improvement. Hence, the aims of this study therefore were:

1. To evaluate the supplementation effect of chekaresidue on body weight gain and nutrient digestibility of yearling Woyto-guji goats.

2. To determine cheka-residue as an economic source of energy feed to replace wheat bran.

\section{MATERIAL AND METHODS}

\section{Description of the study area}

The experiment was carried out on former Konso Woreda now a day Konso Zone, Baide station which is located at about $595 \mathrm{~km}$ south of Addis Ababa and $365 \mathrm{~km}$ to the south west of the regional capital. It is a part of Southern nation nationalities and People's region situated nearly to the center of the region with an astronomical location of roughly $5^{\circ} 15^{\prime \prime} \mathrm{N}$ latitude and $37^{\circ} 29^{\prime \prime E}$ longitude lines. According to Ethiopian Census Report (2012), the district has a total area of $2,273.79$ sq. $\mathrm{km}$ with a population of 235,087. The area received 519 to $1094 \mathrm{~mm}$ annual rainfall, and has an average of 25 and $30^{\circ} \mathrm{C}$ of minimum and maximum temperature, respectively, with an altitude of 550 to $2100 \mathrm{~m}$ above sea level.

In regards to the climate, the Woreda is classified into two ecological zones i.e. dry Kola and dry Woyna dega which comprise 70 and $30 \%$ of the total land area, respectively. Rainfall is a bimodal type: the main rainy season is locally known as Hagaya (March-May) and the shorter rains as Katana (September-November). The area is high in human and livestock density with the estimated livestock number of 146,913, 33,526, 59,894, 4,216 and 52,535 for cattle, sheep, goat, equine and poultry, respectively (Experts of Woreda Board, personal communication).

\section{Management of experimental animal}

Twenty (20) yearling intact woyto-guji goats weighing $18.6 \pm 2.14 \mathrm{~kg}$ were selected from Baide Community Based Breeding Program (CBBP) Associations. They were treated against internal and external parasites as per the recommended dosage. They were also vaccinated against ovine pasturelosis, the most common disease of the area, and housed in individual pens equipped with feeding and 
Table 1. Treatment setup.

\begin{tabular}{|c|c|c|c|c|}
\hline \multirow{2}{*}{ Treatments } & \multirow{2}{*}{ Basal diet } & \multicolumn{3}{|c|}{ Supplements } \\
\hline & & CR (Its/d) & WB (g/d) & $\operatorname{NSC}(g / d)$ \\
\hline T1 & Grazing & 1.8lts $(100 \%)$ & 0 & $100 \mathrm{~g}$ \\
\hline $\mathrm{T} 2$ & Grazing & 0.6 lts $(25 \%)$ & $132 \mathrm{~g}(\%)$ & $100 \mathrm{~g}$ \\
\hline T3 & Grazing & 1.2Its $(75 \%)$ & $68 \mathrm{~g}(25 \%)$ & $100 \mathrm{~g}$ \\
\hline T4 & Grazing & $200 \mathrm{~g}(100 \%)$ & $225 \mathrm{~g}(75 \%)$ & $100 \mathrm{~g}$ \\
\hline T5 & Grazing & 0 & 0 & $100 \mathrm{~g}$ \\
\hline
\end{tabular}

CR: Cheka-residue, WB: Wheat bran, NSC: Noug sees cake, Its/d: litters per day and g/d: gram per day.

watering troughs. During the experiment, animals were penned individually and divided into five groups (Table 1) of four animals each. Animals were adjusted for their age and body weight and those having similar age and body weight were randomly assigned to one of the five treatment feeds (Table 1) for three months in individual feeding pens with concrete floors. The trail was done for 90 days of feeding and 7 days digestibility trial following 15 days adaptation period.

\section{Experimental diet management}

Grazing area was fenced with bamboo tree purchased from Bonke area. It was partitioned into 3 equal paddocks by considering the carrying capacity and rotational system of grazing was used to control the animals and manage grazing lands from damage. Animals were allowed to graze for 8 hours per day. Goats were supplemented with $200 \mathrm{~g}$ on dry matter basis wheat bran and cheka-residues interchangeably, at $3.5 \%$ of their body weight with fresh and clean water provided ad libitum. Each treatment group received uniformly $100 \mathrm{~g}$ of nuoge seed cake per day to balance the protein requirement of the experimental animals.

Cheka-residue was collected from the local producers and pre-determined for its nutrient compositions before actual experiment. Cheka-residue was adjusted according to daily DM requirement of the animal and offered in liquid base $(0.6 \mathrm{~L} / 68 \mathrm{~g}$ to $1.8 \mathrm{~L} / 200 \mathrm{~g}$ per day) i.e., cheka-residue has $11.8 \%$ DM. However, wheat bran and noug-cake were purchased from Arba-Minch livestock feed enterprise. The treatment diets were offered twice a day in equal quantities at 8:00 am and 5:00 pm to each experimental buck. Feed offered to the experimental animals and corresponding refusals were recorded daily throughout the experimental periods to determine daily feed intake. Body weight measurements were taken every 15 days after overnight fasting using suspended spring balance and daily weight gain was determined as a difference between final and initial body weight divided over the feeding days. Feed conversion efficiency was calculated as the proportion of daily weight gain to daily dry matter intake.

\section{Chemical composition analysis}

Representative samples of daily feed offers, refusals and feces were ground to pass through a $1 \mathrm{~mm}$ sieve screen size. The ground samples were analyzed for contents of dry matter (DM), ash, crude fiber (CF) and nitrogen at Arba Minch University, Soil Laboratory using the procedure of AOAC (2006), whereas crude fiber content was analyzed following the procedure of Van Soest and Robertson (1991). The crude protein (CP) was computed as N x 6.25. Feces were collected and weighed every morning for each animal before giving of feed or water. In addition, amount of feed offered and refusals were collected, weighed and recorded. The apparent digestibility coefficient of dry matter (DM), organic matter (OM) crude protein (CP) and crude fiber (CF) was calculated using the following equation (McDonald et al., 2002):

$$
\text { NDC }(\%)=\frac{\text { nutrient intake- nutrient excreted in feces }}{\text { Nutrient intake }} \times 100
$$

Where: NDC = Nutrient digestibility coefficient.

\section{Statistical analysis}

The statistical model used for the experiment was: $Y=\mu+$ $X_{i}++e_{i j}$, where, $Y=$ is the response variable, $\mu=$ is the overall mean, $X_{i}=$ is variation due to treatment effect and $e_{i j}=$ is variation due to error. The software package applied for statistical processing of the results was SPSS version 20. Duncan's test was used for pair-wise comparisons to determine differences between means of treatments.

\section{Economic analysis}

Partial budget analysis was performed to evaluate the economic advantage of the different treatment feeds by using the procedure of Ibrahim and Olaloku (2000). The partial budget analysis was involved in the calculation of variable costs and benefits. The selling price difference of bucks in each treatment before and after the experiment was considered as total return (TR) in the analysis. For the calculation of the variable costs, the expenditures incurred on different treatment feeds were taken into consideration. The cost of the feeds was computed by multiplying the actual feed intake for the whole feeding period with the prevailing prices. At the time of feed purchasing, the prevailing price of the feeds including the transportation 
Table 2. Chemical composition characteristics of the experimental feeds (Cheka-residue, Wheat bran and Noug seed cake).

\begin{tabular}{lccccccc}
\hline Feed Items & DM \% & Ash\% & OM\% & CP\% & NDF\% & ADF\% & ADL\% \\
\hline CR-Konso & 12.1 & 3.09 & 96.91 & 20.11 & 28.68 & 18.56 & 4.56 \\
CR-Derashe & 13.5 & 3.09 & 96.91 & 18.09 & 39.6 & 26.80 & 6.58 \\
CR-A/Minch & 11.6 & 4.1 & 95.88 & 17.42 & 42.07 & 30.93 & 8.74 \\
Average & 12.4 & 3.4 & 96.6 & 18.54 & 36.78 & 25.43 & 6.63 \\
Wheat bran & 89.7 & 6.6 & 93.4 & 16.8 & 45.9 & 27.74 & 2.8 \\
Noug seed cake & 92.3 & 10.4 & 89.6 & 31.4 & 39.2 & 27.24 & 8.4 \\
\hline
\end{tabular}

DM: Dry matter, OM: Organic matter, CP: Crude protein, NDF: Neutral detergent fiber, ADF: Acid detergent fiber and ADL: Acid detergent lignin.

cost incurred to move them to the experimental site was calculated. The labor cost was found to be constant for all the treatments.

Partial budget method measures profit or losses, which are the differences between gains and expenses for the proposed change and includes calculating net return (NR), i.e., the amount of money left when total variable costs (TVC) are subtracted from the total returns (TR):

$$
\text { NR }=\text { TR-TVC }
$$

Total variable costs include the costs of all inputs that change due to the change in production technology. The change in net return $(\Delta N R)$ were calculated by the difference between the change in total return $(\Delta T R)$ and the change in total variable cost $(\triangle T V C)$, and this was to be used as a reference criterion for decision on the adoption of a new technology.

$\Delta \mathrm{NR}=\Delta \mathrm{TR}-\Delta \mathrm{TVC}$

The marginal rate of return (MRR) measures the increase in net income $(\Delta N R)$ associated with each additional unit of expenditure ( $\triangle T V C)$. This is expressed by percentage.

$M R R \%=(\Delta N R / \Delta T V C) \times 100$

\section{RESULTS AND DISCUSSION}

\section{Chemical composition characteristics of the experimental feeds}

Chemical composition characteristics of the feed items used during the experiment are given in Table 2. Chekaresidue was pre-determined for its chemical composition before actual experiment. The sample for cheka-residue was taken from Konso, Derashe and A/Minch, the three most cheka producing areas and the average values were reported here. The study showed that cheka-residue from all sampling sites exhibited high moisture content. Though it had significantly low DM\%, it is one of the energy source concentrate containing easily digestible carbohydrates $(\alpha-$ linked polysaccharides) with high potential energy. The residue also has a high protein content of about $18.5 \%$ (Table 2) and is a relatively good source of other nutrients like OM\%. Cheka-residue has low fiber contents (NDF, $A D F$ and $A D L$ ) which are almost comparable to high quality commercial feed (wheat bran) except for ADL that exhibited a slightly higher value (Adugna, 2009).

\section{Weight gain of goats}

The mean weight gains of male Woyto-guji goats supplemented with high energy feed that consisted of wheat bran and cheka-residue after grazing in order to simulate (partially) the extensive feeding management condition that operates under pastoralist management is given in Table 3. Supplementation of yearling goat has turned out to be much effective in improving live weight gain of experimental goats in the current study. The results showed that the bucks in T1 $(13.8 \mathrm{~kg})$ and T4 $(12.93 \mathrm{~kg})$ gained significantly ( $p$ better than the bucks in all other treatment groups) followed by T3 and T2. However, the results for T1 and T4 did not differ statistically; reflecting that supplementation of cheka-residue almost equally affected the body weight gains of bucks as supplementation of wheat bran. Consequently, goats attained market live weight of 29.85 to $31.83 \mathrm{~kg}$ at their yearling age when fed for 90 days. The lowest body weight gain was recorded with T5 (Control group) as compared to the supplemented treatments (T1, T2, T3 and T4) and could be due to relatively lower crude protein and higher fiber contents of the basal feeding or better nutrients utilization of goats in supplemented groups. Similar observation has been reported by Yadav and Khan (2011).

\section{Nutrient digestibility of experimental feeds}

There was a significantly $(p \leq 0.05)$ higher dry matter, organic matter, crude protein and crude fiber digestibility between supplemented and control groups (Table 4). The digestibility of all analyzed nutrients for the supplemented groups was increased. But, there, was no significant difference in digestibility among the supplemented treatments i.e. T1, T2, T3, and T4. This might be due to 
Table 3. The weight gain of goats as affected by supplementation of energy feeds (CR and WB).

\begin{tabular}{lcccc}
\hline \multirow{2}{*}{ Treatments } & & \multicolumn{3}{c}{ Mean weight gain $\mathbf{( k g )}$} \\
\cline { 3 - 5 } & $\mathbf{N}$ & FWG & MWG & DWG \\
\hline T1 & 4 & $13.80^{\mathrm{a}}$ & $0.460^{\mathrm{a}}$ & $0.153^{\mathrm{a}}$ \\
T2 & 4 & $10.82^{\mathrm{bc}}$ & $0.361^{\mathrm{bc}}$ & $0.120^{\mathrm{bc}}$ \\
T3 & $10.98^{\mathrm{abc}}$ & $0.366^{\mathrm{abc}}$ & $0.122^{\mathrm{abc}}$ \\
T4 & $12.93^{\mathrm{ab}}$ & $0.431^{\mathrm{ab}}$ & $0.144^{\mathrm{ab}}$ \\
T5 & 4 & $9.77^{\mathrm{c}}$ & $0.326^{\mathrm{c}}$ & $0.109^{\mathrm{c}}$ \\
SEM. & 4 & 0.665 & 0.022 & 0.007 \\
Sig. & 4 & 0.047 & 0.047 & 0.047 \\
\hline
\end{tabular}

a.b.c Means within rows having different superscript are significantly different at $(p<0.005)$. FMG: Final weight gain; MWG: Monthly weight gain and DWG: Daily weight gain.

Table 4. Nutrient digestibility of treatment feeds used in the experiment.

\begin{tabular}{llcccc}
\hline \multirow{2}{*}{ Treatments } & N & \multicolumn{4}{c}{ Mean nutrient digestibility \% } \\
\cline { 3 - 5 } & 7 & DMD\% & OMD\% & CPD\% & CFD\% \\
\hline T1 & $77.73^{\mathrm{a}}$ & $79.99^{\mathrm{a}}$ & $98.57^{\mathrm{a}}$ & $82.75^{\mathrm{a}}$ \\
T2 & 7 & $78.64^{\mathrm{a}}$ & $80.44^{\mathrm{a}}$ & $97.22^{\mathrm{a}}$ & $84.20^{\mathrm{a}}$ \\
T3 & 7 & $77.93^{\mathrm{a}}$ & $80.85^{\mathrm{a}}$ & $96.89^{\mathrm{a}}$ & $82.51^{\mathrm{a}}$ \\
T4 & 7 & $80.56^{\mathrm{a}}$ & $83.48^{\mathrm{a}}$ & $99.84^{\mathrm{a}}$ & $85.00^{\mathrm{a}}$ \\
T5 & 7 & $67.75^{\mathrm{b}}$ & $65.43^{\mathrm{b}}$ & $81.09^{\mathrm{b}}$ & $79.46^{\mathrm{b}}$ \\
SEM & 3.18 & 3.415 & 1.78 & 3.58 \\
\hline
\end{tabular}

a.b.c Means within rows having different superscript are significantly different at $(p<0.005)$. DMD: Dry matter digestibility; OMD: Organic matter digestibility; CPD: Crude protein digestibility and CFD: Crude fiber digestibility.

Table 5. Economic analysis of the experiment.

\begin{tabular}{lcccccc}
\hline \multirow{2}{*}{ Treatments } & \multirow{2}{*}{$\mathbf{N}$} & \multicolumn{5}{c}{ Mean cost \& Income per animal (birr) } \\
\cline { 3 - 6 } & & Tcos/anl & Vcos & GFS & NI & MRR \\
\hline T1 & 4 & $1090.30^{\mathrm{ab}}$ & $1070.25 \mathrm{ab}$ & $1830.25^{\mathrm{c}}$ & $739.53^{\mathrm{c}}$ & $0.70^{\mathrm{b}}$ \\
T2 & $1209.21^{\mathrm{c}}$ & $1188.81 \mathrm{c}$ & $1716.30^{\mathrm{b}}$ & $507.16^{\mathrm{a}}$ & $0.43^{\mathrm{a}}$ \\
T3 & 4 & $1171.43^{\mathrm{bc}}$ & $1151.05 \mathrm{bc}$ & $1752.40^{\mathrm{b}}$ & $580.92^{\mathrm{a}}$ & $0.52^{\mathrm{ab}}$ \\
T4 & 4 & $1139.20^{\mathrm{abc}}$ & $1118.9 \mathrm{abc}$ & $1771.25^{\mathrm{bc}}$ & $631.83^{\mathrm{bc}}$ & $0.57^{\mathrm{ab}}$ \\
T5 & 4 & $1060.45^{\mathrm{a}}$ & $1039.95 \mathrm{a}$ & $1608.60^{\mathrm{a}}$ & $548.13^{\mathrm{a}}$ & $0.53^{\mathrm{ab}}$ \\
SEM & 4 & 28.03 & 28.3 & 24.6 & 48.76 & 0.067 \\
Sig. & & 0.015 & 0.015 & 0.005 & 0.0471 & 0.038 \\
\hline
\end{tabular}

a.b.c Means within rows having different superscript are significantly different at $(p<0.005)$. Tcos/anl: Total cost per animal; Vcos: Variable costs; GFS: Gain from animal sell; NI: Net income and MRR: Marginal rate of return.

the similarity in energy content of supplemental feeds in the current experiment. On the other hand, there was increasing trend in nutrient digestibility as the proportion of supplementation increased. It might be due to the fact that supplementation improved the apparent digestibility of nutrients which is in line with the result of Terefe et al. (2013) who reported that concentrate supplementation improved weight change, carcass characteristics and DM digestibility of Afar goats.

\section{Partial budget analysis}

The economic efficiency of growing woyto-guji goats by supplementing cheka-residue as a replacement for wheat bran is presented in Table 5. Results from current study showed that, goats grazed on natural pasture as basal diet and supplemented $1.8 \mathrm{l} /$ day cheka-residue as energy source (T1) returned a higher profit than the other treatments which was followed by T4. The net return from 
the experimental treatments was $739.53,507.16,580.92$, 631.83 and 548.13 ETB per head for T1, T2, T3, T4 and T5 respectively.

The total expenditure for feed, medication and related inputs per $\mathrm{kg}$ of total live weight gain were 1090.30, $1209.21,1171.43,1139.20$ and 1060.45 ETB for T1, T2, $\mathrm{T} 3, \mathrm{~T} 4$ and T5 respectively. The difference in control group (T5) and other treatments was due to the difference in live weight gain of the bucks in each treatment, which was a function of differences in feed quality and feed conversion efficiency. The higher net return and rate return in T1 was due to the optimum supplementation of low cost energy feed (cheka-residue) which resulted in higher body weight gain (153 g/day) as compared to the other treatments that had relative body weight gain of 120,122, 144 and 109 g/day for T2, T3, T4 and T5 respectively. This indicated that goat fed with better quality feed perform well and have higher body weight gain and sold at maximum price and earn better net return.

Hence, supplementation of grazing on natural pastures with $1.8 \mathrm{~L} /$ day of cheka-residue was potentially more feasible and economically beneficial than in other treatments which is consistent with the findings of Gebru et al. (2017) who reported that substitution of dried mulberry leaf meal for concentrate mixture reduced total feed cost but linearly increased net return and change in net return of Abergelle sheep.

\section{Conclusion}

Replacing wheat bran by cheka-residue had no confrontational effect on digestion, growth and weight gain performances of bucks provided that energy from wheat bran $(200 \mathrm{~g})$ is replaced by equivalent energy from chekaresidues $(1.8 \mathrm{~L})$. Therefore, it can be concluded that supplementation of grazing on natural pasture with 1.8 L/200g DM cheka-residue (T1) was potentially more feasible and economically beneficial to the livestock owning community to efficiently utilize nutrients in combination with locally available products, that readily digests in the rumen with high energy yielding potential for better goat production performance.

\section{CONFLICT OF INTEREST}

The authors declared that they have no conflict of interest.

\section{ACKNOWLEDGMENT}

The authors would like to acknowledge Southern Agricultural Research Institute for financial support and livestock research technical supporting team of Arbaminch Agricultural Research Center to their endeavor in management of the experimental animals and data collection. The authors would also like to thanks Feed and Nutrition and Animal Health Research Team of ARC for professional involvement and facilitation of the experimental works. Arbaminch University, Nutrition Laboratory Technicians also deserve great appreciations for their help on the experimental sample feed laboratory analysis

\section{REFERENCES}

Adugna, T. (2008). Feed resources and feeding management. A manual for feedlot operators and development workers. SPSLMM Program. Addis Ababa, Ethiopia.

Association of Official Analytical Chemists (AOAC) (2006). Official Methods of Analysis, 18th ed., AOAC International, Gaithersburg, MD Association of Official Analytical Chemists. Washington, D.C

Ayalew, W., Dorland, A. V., \& Rowlands, J. (2004). Design, execution and analysis of the Livestock breed survey in Oromiya Regional State, Ethiopia. Oromiya Agricultural Development Bureau, Addis Ababa, Ethiopia and International Livestock Research Institute, Nairobi, Kenya.

Aziz, A. M. (2010). Present status of the world goat populations and their productivity. Lohmann Information, 45 (2), 42-52.

Behnke, R. (2010). The Contribution of livestock to the economies of IGAD member states: Study findings, application of the methodology in Ethiopia and recommendations for further work. IGAD LPI Working Paper No. 02-10.

Binitu, W. B., Gemede, H. F., \& Woldegiorgis, A. Z. (2018). Nutritional and alcoholic contents of cheka: A traditional fermented beverage in Southwestern Ethiopia. Food Science and Nutrition, 6(8), 2466-2472.

Ethiopian Census Report (2012). Population and housing census of Ethiopia. Central Statistical Authority, Addis Ababa.

Ethiopian Livestock Master Plan (LMP) (2015). Institutions and policies to implement the Ethiopia livestock master plan Ethiopia LMP brief. International Livestock Research Institute, Box 5689, Addis Ababa, Ethiopia.

FAOSTAT (2016). Food and agricultural organization of the United Nations, statistical division.

Food and Agriculture Organization of the United Nations (FAO) (2004). Livestock sector brief: Ethiopia. Livestock information, sector analysis and policy branch (AGAL), FAO, Rome, Italy.

Gebru, D. T., Khushi, Y. R., \& Tedla, T. A. (2017). Substitution of dried mulberry (Morus indica L.) leaf meal for concentrate mix on feed intake, digestibility, body weight gain and carcass characteristics of Abergelle sheep. International Journal of Livestock Production, 8(4), 48-56.

Gizaw, S., Tegegne, A., Gebremedhin, B., \& Hoekstra, D. (2010). Sheep and goat production and marketing systems in Ethiopia. Amhara Regional Agricultural Research Institute, Bahir Dar, Ethiopia., Improving Productivity and Market Success (IPMS) of Ethiopian Farmers Project, International Livestock Research Institute (ILRI), Addis Ababa, Ethiopia.

Ibrahim, H., \& Olaloku, E. (2000). Improving cattle for milk, meat and traction. ILRI Manual 4. ILRI (International Livestock Research Institute), Nairobi, Kenya. p.135.

McDonald, P., Edwards, R. A., Greenhalgh, J. F. D., \& Morgan, C. A. (2002). Animal nutrition. 6th Edition, Prentice Hall, London. Pp. 471-581.

Terefe, E., Yaqob, Y., Dessalegn, K., Tafa, A., Kifle, A., Gebregziabher, W., \& Tesfamariam, W. (2013). Market weight 
and carcass characteristics of intact yearling afar goats under semi-intensive feeding management. International Journal of Livestock Production, 4(6), 95-101.

Van Soest, P. V., Robertson, J. B., \& Lewis, B. (1991). Methods for dietary fiber, neutral detergent fiber, and nonstarch polysaccharides in relation to animal nutrition. Journal of Dairy Science, 74(10), 3583-3597.
Yadav, C. M., \& Khan, P. M. (2011). Effect of grazing and supplementary feeding on growth of growing goats under field condition. Indian Journal of Small Ruminants, 17(1), 103-104. 